\title{
Narratives of fathers' experiences of the stillbirth or neonatal death of their infants
}

\author{
今 村 美代子 (Miyoko IMAMURA)*
}

抄録

\section{目 的}

死産または新生児死亡により子どもを亡くした父親が，妻の妊娠中から現在までにどのような体験を してきたのかという語りを記述し，それを通して父親をより深く理解し，求められるケアの示唆を得る ことである。

\section{対象と方法}

死産または新生児死亡で子どもを亡くした6名の父親を対象に半構成的面接を行い，現象学的研究方 法を参考に質的記述的に分析した。

\section{結 果}

父親の体験は，以下の7つに分類された。1. 予期せ女死に衝撃を受ける：子どもを突然に失ったとい う，驚きや混乱からもたらされた精神的衝撃，そして，その後に引き続く無力感，空虚感であった。2. 自分の悲しみをこらえ妻の心身を案じる：自分の悲しみよりも先に，心も身体も傷つけられたであろう 妻の立場を気遣っていた。3. 辛さを隠し父親・夫としての役割を果たす：自分の辛さを押し隠し，子ど もを送り出す為の諸々の手続きを引き受け，父親と夫の両方の役割を果たしていた。4. 社会に傷つけら れながら生活を続ける：男性の備え持つ特性により，悲しみは内に抱え込まれたまま表出されず，更に 子どもの死を嘆き悲しむことを認めない社会に傷つけられていた。5. 子どもの死因を知りたいと望む： 子どもの死に対して何らかの意味付けを行い，死を受容してゆくきっかけとしていた。6. 父親として在 り続ける：子どもが誕生する以前からその存在を愛しみ，子どもをしくした後も父親として在ることに 変わりなかった。7. 人間的な成長を遂げる: 父親達は悲しみを抱えながらも「自分自身の力で乗り越え た」, 死生観が変容した, 人生観が変容した, 自分の体験を他者に生かして「共有」したいと願った。

\section{結 論}

死産・新生児死亡によって子どもを亡くした父親は，予期せ女我が子の死に大きな衝撃を受け，悲し みを押し隠しながらも父親と夫の役割を果たしていた。表面化されない悲しみは社会からも見過ごされ， 時に父親自身も気付き得ないほどであったが，亡き子どもの存在を忘机ることはなく，父親として在り 続けることで人間的な成長を遂げていた。

キーワード : 死産, 新生児死亡, 父親, 周産期喪失, 現象学的研究

\footnotetext{
*1 聖路加看護大学看護実践開発研究センター客員研究員 (St. Luke's college of nursing research center for development of nursing)
} 


\section{Objective}

\section{Abstract}

In the present study, narratives of fathers who lost children to stillbirth or neonatal death are described with regard to their experiences from during their wive's pregnancies to the present in order to gain a deeper understanding of fathers who lost children and thereby obtain suggestions for necessary care.

Subjects and Method

A semi-structured interview was conducted with 6 fathers who had lost children to stillbirth or neonatal death. A qualitative descriptive approach based on phenomenological research methodology was used to analyze the obtained data.

Results

The experiences of the fathers who lost children to stillbirth or neonatal death were grouped into the following 7 categories.

1. Shock due to the child's unexpected death. The sudden loss of the child resulted in surprise and confusion, which in turn caused psychological shock followed by feelings of helplessness and emptiness. 2. Fathers' concern for their wives and suppression of their own sorrow. Fathers were more worried about their wives, who were going through both physical and mental hardships, than their own sorrow. 3. Maintaining father and husband roles while hiding their pain. Fathers played roles as both father and husband by working on various procedures for sending off their children, while at the same time hiding their pain. 4. Social stigma and pain in daily life. Fathers were not able to express their grief due to the expectations placed on men by society, and they experienced emotional pain at society's unwillingness to recognize their grief over the children's death. 5. Wishing to know the cause of death. Fathers attempted to find meaning in their children's deaths, and tried to accept the death. 6 : Continuing to be a father. Fathers had already come to love their children before the birth, and did not give up this parental role even after the death. 7. Maturing as a person. The grieving fathers "overcame the hardship on their own," acquired a new view of life and death and a new view of existence, and wished to share their experiences to help other people.

Conclusion

Fathers who lost children to stillbirth or neonatal death were terribly shocked by the unexpected death of their children, but continued to play roles as both father and husband after the death, while at the same time suppressing their own grief. Their unexpressed pain was overlooked by society, and sometimes went unnoticed even by the fathers themselves; however, they never forgot the children they lost. This allowed the fathers to continue being fathers and to mature as human beings.

Keywords: stillbirth, neonatal death, father, perinatal loss, phenomenological research

\section{I.はじめに}

健やかな子どもの誕生を信じて待つ夫婦や家族にと って，まだ見め子どもを亡くすという体験は，その後 の精神状態と身体的回復に多くのエネルギーを要する。 さらに，両親らの将来への望みと夢の哀失をも心に抱 かせるものであると言われている (McCreight, 2004 ; Murphy, 1998)。過去30年来，海外においては周産期 死亡の悲嘆をはじめとする関連研究が多数取り組まれ ている。しかしながら，周産期の喪失に引き続いて起 こる反応や影響に関する経験については，その多くが 母親についてのみ述べられているものであり, それに 比して父親に関する研究は少ない。 周産期における㳖失の悲嘆反応の男女比較研究にお いて, 父親の悲嘆過程は女性よりも早く経過し, 受 ける衝撃も少ない(Condon, 1986 ; Hughes \& PageLieberman, 1989 ; Kavanaugh, 1997) という報告がな
される一方，父親も母親と同様に，我が子を失った際 に大きな衝撃を受けて苦悩し，時にはその嘆きが母親 より遅れて見られるなど独特な父親の悲嘆過程も報 告されている (Dyregrov \& Dyregrov, 1999 ; Stinson, Lasker, Lohmann, et al.,1992 ; Vance, Boyle, Najman, et al.,2002)。

Badenhorst, Riches, Turton et al. (2006) は死産・新 生児死亡により子どもを亡くした父親への心理的影 響について，1966年から2005年までの79編の研究よ り, 一定基準を満たした質的研究 3 編と量的研究 14 編 を合わせた 17 編の研究をシステマティック・レビュー している。量的研究の多くでは不安や抑うつ症状につ いて取り組まれているが，これらも父親は母親よりも 不安や抑うつ状態が低いレベルであったと報告された。 また, 不安や抑うつで示される以外に, 複雑に入り組 む，いまだ把握されていない悲嘆反応を測定すること には限界があると指摘している。さらに, 質的研究の 
傾向は古典的な悲嘆反応を述べ，父親は母親ほど罪悪 感を感じず，社会的役割やカップル間に潜在する葛藤 を体験したことが強調されていた。

我が国の周産期の喪失におけるケアへの取り組みは, 欧米に比して遅れをとるものであり，近年ようやくそ の現状 (藤村 - 安藤, 2004 ; 岡永, 2005) とケア (蛭田, 2009 ; 石井，2006 ; 大井，2001a.b ; 太田，2006）に関 して母親の視点から取り組まれるようになったが，父 親に焦点をあてた研究は，まだ少数である。そこで本 研究では，死産または新生児死亡により子どもを亡く した父親が，妻の妊娠中から現在までにどのような体 験をしてきたのかという語りを記述し，それを通して 死産・新生児死亡で子どもを亡くした父親をより深く 理解し，求められるケアの示唆を得ることを目的とす る。なお，本研究では，妻の出産時から現在までの部 分を発表することとした。

\section{II. 研究方法}

\section{1. 研究デザイン}

父親の語りを通じて記述する質的記述的研究である。

\section{2. 研究参加者}

死産 (自然死産)または新生児死亡により子どもを 亡くした父親で，以下の条件を満たし，研究協力の承 諾が得られた 6 名とした。(1)妊娠 12 週以降の死産また は生後28日未満の新生児死亡により子どもを亡くし た父親。(2)喪失からの期間は，原則として 1 年半以上 から 10 年未満。 1 年半以上としたのは，喪失後 1 年に おいて命日や記念日を経ることで，悲しみを想起させ うるきっかけを避けるためである。また，時間の経過 に伴うバイアスを考え10年と定めた。(3)日本で死産 ・新生児死亡を経験した，日本語が話せ読み書き出来 る方。研究参加者は以下の手順を経てリクルートした。 セルフヘルプグループの代表者から，悲嘆の状況が落 ち着き，語る体験が精神的負担にならないと予測され た方を紹介頂いた。その後, 研究者より研究の主旨・ 方法，倫理的配慮，研究公表の可能性を口頭および文 書を用いて説明し，同意を得た。

\section{3. データ収集の方法}

データ収集は，インタビューガイドを用いた半構成 的面接法で行った。なお，インタビューガイドは本研 究の空口である，周産期喪失体験者かつ心理学の専門
家であるセルフヘルプグループ代表者に先だって確認 してもらい，模擬面接を行った。死産・新生児死亡を 経験した父親の研究が少ないことや，他者に自身の内 面を開示しない等の男性特有の背景を踏まえ，研究参 加者の立場が脅かされ女よう, 研究参加者のペースに 沿ってインタビューを進めた。また，質問することに よって語られる内容の前後関係を急に変化, 断片化さ せないためにも，インタビューガイドに沿うような質 問ではなく，研究参加者から語られる流れを大切にし た。インタビューは原則として 1 人 1 回，時間を 1 時間 と計画したが，研究参加者の思いの表出の場ともなり 意向に添って延長をした。場所は，研究参加者が希望 する場所・時間帯に行った。研究参加者の自宅以外の 場合は，大学や区の施設等のプライバシーが保護され た場所を使用した。

\section{4.データ収集期間}

2007 年 7 月から 2007 年 10 月であった。

\section{5. データ分析の方法}

本研究は, 死産・新生児死亡で子どもを亡くした父 親の持つ複雑で困難な体験に近づくために，現象学的 アプローチを参考にした。分析は，Giorgi (2004)の分 析手順を参考にして，以下の過程を辿ることを目指し た。(1)インタビュー内容を逐語録に起こし，そこにイ ンタビューの際に観察したデー夕を加えて丹念に読み 込み，語りの記述全体を把握する。(2)逐語録を読みな がら父親の体験を，妻の妊娠中，子どもの喪失，現在 に至るまでの時期に分ける。(3)逐語録の中で，同じ状 況について語られている部分，それに付随する感情の 表現を一つの構成要素とし，その状況を研究参加者が ぞのように意味付けているのか把握する。(4)各構成要 素を，それを特徵づける研究参加者が実際に語った言 葉で表す。(5)研究参加者の実際の言葉を, 研究者の言 葉に置き換えながら構成要素ごとに記述する。(6)各構 成要素を経時的に並べ，父親の体験した世界を一つの ストーリーにまとめ, 研究参加者に記述内容に相違が ないか確認をして頂き，内容の追加・修正を行う。(7) 研究参加者の個々の記述を繰り返し読み，体験した世 界を研究者が解釈し，体験の中心的な意味を見出す。 8)個々の研究参加者の記述から現象の全体構造を把握 し，共通する意味の類型化を試みる。

デー夕分析の際には，デー夕分析の信頼性と妥当性 を高めるために，デー夕の収集・分析・解釈の過程に 
おいて, 研究初期段階より母性・助産学, および社会 学の専門家, さらに周産期の㗏失に取り組む専門家と, 死産体験者かつ心理学の専門家によるスーパービジョ ンを受けた。

\section{6. 倫理的配慮}

本研究への協力は自由意思に基づくものであり，い ずれの時点においても拒否による不利益は生じないこ とを保証した。面接時は，心理的な脅かしを防ぐこと に細心の注意を払い，デー夕の匿名性を確保し，プラ イバシーを厳守した。万一, 研究協力によって研究参 加者に精神的負担が生じた事を想定し，セルフヘル プグループの運営者にフォローアップを依頼する体制 を整えた。なお，本研究計画書の段階で，聖路加看護 大学倫理審査委員会の承認を得られたのちに実施した （2007年6月17日 承認：受理番号07-023）。

\section{III. 結果}

本研究参加者は死産を経験した父親 3 名，新生児死 亡を経験した父親 3 名の計 6 名であり，年齢は 31 歳か ら 48 歳であった。研究参加者の背景は表1に示す。イ ンタビュー所要時間は 1 時間から 3 時間をかけ，平均 2 時間であった。

研究参加者と死児に関しては，アルファベットの頭 文字で示し, 研究参加者自身の言葉は「」, その他の
者が語った言葉は『』，分かりにくい文脈には（）内 に補足し提示した。

1. A氏の体験：30代。娘の Gちゃんをしくして 1 年 2 ケ月経過していた。

〈A氏の体験の解釈〉 二度の流産の後に授かった待望 の女の子が，障害を持って生まれ，亡くなったことに 二重のショックを受け, 現在もその死に納得をしてい ない。計り知れない苦悩を敢えて外には出さず，妻を 支えながら社会に戻ったが，妻が立ち直りを見せた半 年後に自らが受けた負荷の大きさに気付かされた。

1）妊娠 30 週という時を通して強まっていた家族の 絆に気付く

我が子が障害を持ち，亡くなったという事実に「二 重のショック」を受けたA氏は,「頭が真っ白」なまま 医師からの説明を受けた。その後, 6歳の息子に $\mathrm{G} 5$ ゃんの死を告げたところ，思いがけず大粒の涙を見せ られたことにA氏は驚き，動摇した。A氏の一家にと って Gちゃんと過ごした時間は，悲しみの中にも「家 族が揃ったっていう雾囲気」であったと感じられた思 い出であり，Gちゃんを抱っこして家族写真を撮り, この世に生まれてきた証を記憶と品物に残していた。

2 ）他者からの対応が空虚感，孤独感をもたらす

A氏にとって「Gを燃やさなくてはいけない」ことが, 一番辛いことであった。しかし「全部自分がしないと いけない」と, 自身を厳しく律し, 役所への死産証書

\section{表1＼cjkstart研究協力者の属性}

\begin{tabular}{|c|c|c|c|c|c|c|c|c|c|c|}
\hline & \multirow{2}{*}{ 年龄 } & \multirow{2}{*}{ 初経産 } & \multirow{2}{*}{$\begin{array}{l}\text { 死児の } \\
\text { 同 胞 }\end{array}$} & \multicolumn{4}{|c|}{ 死児情報 } & $\begin{array}{l}\text { 䘫失からの } \\
\text { 期 }\end{array}$ & \multirow{2}{*}{$\begin{array}{l}\text { 分婏 } \\
\text { 様式 }\end{array}$} & \multirow{2}{*}{ プロフィール } \\
\hline & & & & 死亡原 & & 週数 & 性别 & 期 間 & & \\
\hline A & 30 代 & 経産 & 兄7歳 & 死産 & 不明 & 30 週 & 女児 & 1年 2 ケ月 & $\begin{array}{l}\text { 緊急 } \\
\text { CS }\end{array}$ & 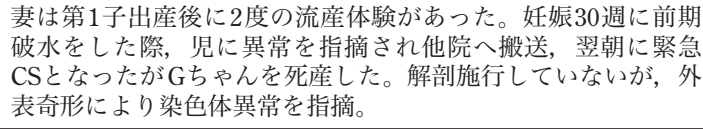 \\
\hline B & 40代 & 初産 & 弟7歳 & 死産 & 不明 & 36週 & 女児 & 8年10ケ月 & $\begin{array}{l}\text { 経腔 } \\
\text { 分婏 }\end{array}$ & 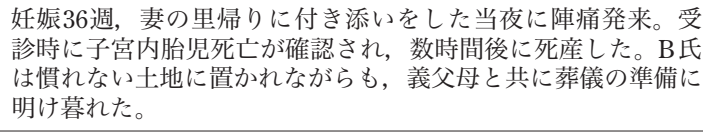 \\
\hline $\mathrm{C}$ & 30 代 & 初産 & 弟2ヶ月 & 死産 & $\begin{array}{l}\text { 臍帯 } \\
\text { 因子 }\end{array}$ & 39週 & 女児 & 2年3 ケ月 & $\begin{array}{l}\text { 経膣 } \\
\text { 分婏 }\end{array}$ & 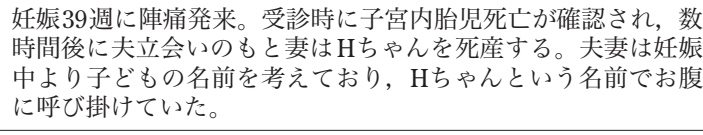 \\
\hline D & 30 代 & 初産 & $\begin{array}{l}\text { 双子の } \\
\text { 妹7歳 }\end{array}$ & $\begin{array}{l}\text { 新生児死亡 } \\
\text { (生後30時間) }\end{array}$ & $\begin{array}{l}\text { 先天性 } \\
\text { 心疾患 }\end{array}$ & 36週 & 女児 & 7年5 ケ月 & $\begin{array}{l}\text { 予定 } \\
\text { CS }\end{array}$ & $\begin{array}{l}\text { 双胎のため, 妊娠 } 36 \text { 週で予定帝王切開術を施行。出産直後に } \\
\text { 第一 }(\text { Iちゃん)の先天性心疾患が発見され，D氏と義母に㛜 } \\
\text { しい予後宣告がなされた。 }\end{array}$ \\
\hline $\mathrm{E}$ & 30 代 & 初産 & 妊娠中 & $\begin{array}{l}\text { 新生児死亡 } \\
\text { (生後 } 40 \text { 分) }\end{array}$ & 不明 & 24週 & 男児 & 2 年 & $\begin{array}{l}\text { 経臸 } \\
\text { 分婏 }\end{array}$ & $\begin{array}{l}\text { 妻は妊娠初期より長期入院や自宅安静を経験していた。妊娠 } 24 \\
\text { 週, 三度目の入院中に分婏進行し，700g台でJ君を出産。E氏 } \\
\text { が病院に駆けつけた頃, J君は妻に抱かれなが息を引き取う } \\
\text { うとしていた。 }\end{array}$ \\
\hline $\mathrm{F}$ & 40代 & 初産 & 弟 9 ヶ月 & $\begin{array}{c}\text { 新生児死亡 } \\
\text { (生後 } 2 \text { 日) }\end{array}$ & 肺炎 & 41週 & 男児 & 2 年7ヶ月 & $\begin{array}{l}\text { 経腔 } \\
\text { 分婏 }\end{array}$ & 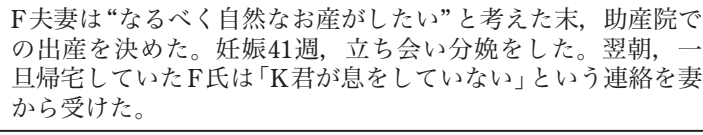 \\
\hline
\end{tabular}


を届け出た。火葬の日取りを「Gと長く一緒に居られ るぎりぎりの時間」まで引き延ばしたが，事務員は表 情も変えず「慣れた手つき」で淡々と業務を行なって いた。葬儀当日，業者が用意した部屋は普段目に付 かない火葬場の隣の「小さな会議室」であった。さら に，人通りの多い受付に $\ulcorner A$ 家・死産」と記載された用 紙が放置されていたのを見て，娘の死が簡単に扱われ 「作業の一環」の如く片付けられていると思った。ま た，我が子の死について直接伝えた覚えのない「第三 者」から声を掛けられたことで，A氏の知らない場で 家族の話が一人歩きしているのではないかという「恐 怖」を抱かせられていた。

Data：「火葬が終わって, その次の週ぐらいから, また出 張に行き出したんですけど，その時にお客さんのほう から『このたびはご愁傷様でした』つて言われたのが... 辛かった。普通に接して，黙っていてくれればいいの に。(上司が) 伝えたと思うんですけど，違う理由で伝え てくれてもいいんじやないかなって…(中略)こつちも グサって刺すような事を言われたら嫌だなと…普通に仕 事をするぞという気持ちで (出張に) 行ったにもかかわ らず，その事 (我が子の死) を伝えた覚えのない第三者 からの一言でその事を思い出させるというのは，辛いし， 怖いというか…」

\section{3 ) 妻に代わって表に立つ}

A氏は，外界とのやりとりを避け，自責の念を抱く 妻の心身を常に案じていた。また，仕事で妻の傍に居 られない分，周囲とのやりとりをすべて担うよう「踏 ん張って」行動していた。日常生活における何気ない 周囲からの声掛けは，A氏にとって逃げ場のないもの となり，さらに辛い気持ちにさせられるものだった。 Data：「退院後の妻は，自分をかなり責めていたんですね。 そこは(私が) 踏ん張らないと。出張行っていて平日は 居ない分ね，妻は保育園の送り迎えも全部やんなきやい けないし…でも人と会いたくないっていう辛い思いをし ているんで，そこはなんとか私がカバーしないといけな い。で，私が辛いって言っちゃうと，妻は何も出来ない じやないですか。妻が一番辛いから…だから仕事先でも あまりそういうのは見せないようにはしていたんですけ どね」

4 ) 我が子の障害の原因に自らを摇らがされる

A氏にとって，Gちゃんが「障害によって奪わ机た」 ことは，「なんでうちの子に」という問いを繰り返させ る「納得出来ない」ものとして在り続けた。Gちゃんの 病理解剖を行わなかったことから，死因は不明なまま
だが，それ故に我が子が障害を持って生まれたのは 「実は，自分達の遺伝子が悪いんじゃないのかな」と， A氏は自身の生殖性をも脅かされていた。A氏は我が 子の喪失から半年後に，パニック障害を発症した。そ れは，妻の元来備え持つ社交性が回復し，外界に目を 向け始めたと同時期であった。

2.B氏の体験：40代。娘を亡くして 8 年 10 ケ月もの 歳月が流れていた。出産前には夫婦で娘の名前を考え ていたが，敢えて名付けはせずに与えられた戒名を大 切にしている。その後, 7歳になる第二子を授かって いる。

〈B氏の体験の解釈〉悲しみから一刻も早く脱して家 族を支えるため，感情に逆らうかのように，我が子と の思い出を一切絶ち切った。しかし，我が子を思う気 持ちは自然と涌き出て止められず，無意識の中にも思 い出を残す自分がいた。我が子が遺してくれたものと して意味を見出した“いのちの大切さ”, “生きること の難しさ”を他者にも分け与えたいと願った。

1 ) 悲しみから早く立直るために我が子の存在を忘れ

ようと決意する

妻の両親と共に病院に駆けつけ，医師からの説明を 受けたが「心臓が止まっている」という言葉を理解す るのに時間を要した。その後，B氏は「すぐに妻が帝 王切開をしなければならない」と思い，医師に妻の安 否を問うた。そして「普通に」出産が出来，妻の命に 別状がないことを保証された言葉に救われた。義父母 の慟哭を目の当たりにしたB氏は，「一刻も早くこの 状況から脱して家族を支えなければならない」と考え た。そのためには，いっそ大切な我が子の存在を忘れ， 「感情に流されない」よう，淡々と家族の為に前へ進 むべきだと決意した。

Data：「(我が子に) 触ってみたいという気持ちはあったん ですけど，触ると，ず一つと尾を引きそうな…この悲し みから逃れられないような気がしたの。…゙ 手を合 わせるのが精一杯だつたんです (中略) 自分もそうだし, 家族も妻もずつと悲しむだろうから，そういうもの(記 憶に残るようなもの) が無い方が, 妻も早＜立直ってく れるんじやないかと，そう考えたんです」

2 ) 自然と湧き出た我が子への愛情を戸惑いながらも 受け入れる

我が子を忘れることは，家族の悲しみを癒す「良い こと」であり,「我が子との思い出を一切残さない」と した決意は，父娘二人きりで過ごす中に大きく摇らい 
だ。我が子を病院から連れ䚻った B氏は, 塞き止めて いた子への愛情を一気に溢れ出す体験をしていた。 Data :「火葬の焼く直前にもう一度布を外して, 思い切っ て顔を見ました。ただ，どうにかなってないかと心配だ ったんですよ。なかなか…すぐそこに籠には(我が子を) 入れてはいるものの, 早く忘れるために, なかなか顔を 見られなかったんですけどね。(中略) その間にいろいろ, 無意識に何かを(してあげようと思って) …今しか, し てあげることが出来ないなあという事って言うと, 例え ば絵本を買ってきて読んであげたりとかね…あ, “ぞう さん”も歌ってあげたな…

3 ) 我が子の死に理由をもたせる

妻の産後入院が一週間を経過した頃，義父母が死産 の原因について疑問を表出するようになった。その様 子を静観していた B氏も同様に，自身なりに原因を見 出そうとしていた。B夫妻は, 里帰り出産のためにし ばらく夫妻が離れて暮らさなければならないというス トレスが原因であり,「誰が悪いわけでもない」と結論 付けていた。そして，次子を授かったとしても「もう 里帰り出産はしない」と固く決意していた。

4 ）亡き我が子が遺した意味を引き継いでゆく

長い年月を重ねた今，B氏は「死産という経験を乗 り越え, 自分自身の力でそれを好循環に変えられた」 と語った。さらに，我が子は生きて存在する以上に 多くの尊い教えを残し，今なお B氏の人生の処する態 度に深く関わる存在である。その教えは，「いのちの 大切さ」,「生きることの難しさ」,「自ら未来をより良 い方向に切り拓くという生き方」，そして「温かな絆 で結ばれる人々との繋がりを大切にする」事であった。 B氏は，喪失から数ヶ月経過した頃に「完全に忘れて しまっては可哀想」と, 我が子に宛てた想いを自身の ホームページに綴っていた。

3. C氏の体験：30代。娘Hちゃんを亡くして 2 年 3 ケ月経過していた。インタビュー当時, 生後 2 ケの 第二子を授かっていた。

〈C氏の体験の解釈〉まだ見娘を失ったことに呆然 とするが, 妻子を案じ, 守り遂げる役割に徹して出産 に立ち会った。唯一，妻には悲しみの感情を表出でき， 妻と共に感情の摇れを体験していたことで, 周囲の無 知に傷付けられた心は少しずつ癒されていた。そして 亡き娘は夫婦の紏を強め, 妻と同様に感謝すべき存在 となっていた。

1）夫として父親として娘の誕生を見届ける
C氏はショックの中にありながら, 妻が帝王切開術 をするのではないかと不安を抱いた。正常分婏が可 能と知ると,「早く出してあげないと Hも妻も可哀想」, 「やっぱり自分の子」であるからと, 以前は躊躇して いた立ち会い出産にも率先して付き添っていた。そし て「うやむやなまま, 亡くすのは嫌だ」と, 死因と断 定された臍帯部の異常も自ら確認していた。

2 ）悲しみを隠して妻を思う

C氏は泣き崩孔る妻を見ては悲しみを増し, 当時の 記憶が曖昧である程に「体を動かしていた」。そして， 「自分がくよくよしていたらどうしょうもない」,「自 分がやらなきゃいけない」と, 葬儀の準備等の役割を 果たし，辛い現実と必死に向き合っていた。

Data：「とりあえず，自分がくよ<よしていたら，どうし ようもないなっていうのがあって…悲しいのは悲しいけ ど, 全然バタバタで全然覚えてないです (中略) 車にも チャイルドシートとか載せてて, “使わないまま降ろす んだな”とか, “全部しまわなきや”とか, “また使う日が くんのかな”とか…とりあえず全部しまっちやわないと 妻に可哀想だし…退院すれば，どうしても目に入っちや うんで (中略) 身体痛めて産んでいる分, 自分より辛い はず‥女つかく10ヶ月もお腹に入れてきたのに」

3 ) 社会との関わりに傷つけられる

周囲からの何気ない一言によって, Hちゃんの死を 悼むC氏の想いや，その辛さは見過ごされていると感 じられ，悲しみを周囲に表出することはなかった。C 氏は，子どもを亡くす体験がない人には「分かる訳が ない」ことであると，自身の中で折り合いをつけよう と努めた。

Data：「旦那さんは二の次っていうと变なんですけど『奥さ ん大丈夫?』って言われて, 自分も辛いけど, やっぱり 妻の方が辛いんだなって思っちやいますよね。でも, や っぱ妻は産んで辛いだろうから。旦那さんも・辛いこと は辛いですよね。(周囲に対して)怒りまでは別に全然な く，俺も辛いんだけどな，みたいな」

\section{4 ）妻との絆が強められる}

周囲との関わりに傷つけられていたが，唯一妻には ありのままの感情を表出し合い，その苦悩を和らげる ことが出来ていた。また, 「Hがいたから私と妻の絆は すごい強まった」と語るほどに，娘の存在を愛おしく 思っていた。今後，Hちゃんの弟が成長した頃に「お 姉ちゃんいるんだよ」と伝えることで，目に見えなく とも, 皆でHちゃんの存在を家族の中に位置付けよう と考えていた。 
Data：「Hがいたから私と妻の絆はすごい強まったと思いま すよ‥逆に。匀論, Hが存在していればそれが一番なん ですけど，その分，お互いを思いやれるのかなって(中 略) ‥Hにに感謝しますよね」

4. D氏の体験：30代。一卵性の双子の第一子Iちゃ んを先天性心疾患により生後 30 時間程で亡くし，7年 が経過していた。

〈D氏の体験の解釈〉 双子の娘の父親になることを待 ち望んでいたが，長女が致死的な心奇形を持って生ま れた事を受け止められないまま失ったことに“何もし てあげられなかった”という後悔が絶えない。娘に会 いたいという願いは自身の死生観を変容させた程強く, 7年の時を経た今も亡き娘を鮮明に想像しては，悲し みが癒えていない自分に気付く。

\section{1）我が子に迫る死を心では理解出来ない}

妊娠 36 週, 朝一番に予定された帝王切開で二人の 娘が生まれた。しかし, 出生直後に助産師が長女Iち やんを抱えて D家一同の前を走り去ったまま，その状 況を知らされることはなかった。夜間まで待合室に残 つていたのは D氏と義母だけであり，共に不安な時を 過ごしていた。同日 21 時頃，医師はD氏と義母に対 して，Iちゃんが「かなり危険な状態」であること告知 し，面会を許した。全身が浮腫しでいて「大きな白い」 Iちゃんと,「小さくて赤い」次女は対照的であり, 病 状の深刻さを痛感させられた。Iちゃんが危険な状態 であることは「頭では分かっていても，心では理解で きない」ものであった。それと同時に，我が子によう やく会え「双子の父親になった」喜びと「興奮状態」に あった D氏は，父親であるという実感は増し，さらに 娘を愛おしく思う気持ちが溢れ出た。

2 ）冷静に幾つもの役割を果たそうと努める

Iちゃんを失った直後「自分がしつかりして，ちゃ んと送り出してあげなきや」,「妻の悲しみの大きさは 僕とは比べ物にならない」という思いを胸に，「妙に冷 静に」様々な役割を果たしていた。親しい友人に電話 報告をする際も、「冷静に話そうとしたのに」鳴咽をあ げて泣いてしまったことに，D自身が驚いたと語る。 また，Iちゃんの死因を明らかにすべく病理解剖を希 望し，次女に影響が及ばないことを知って安堵した。 D氏は，Iちゃんが身をもって「教えてくれた」結果を 直ぐに妻に知らせていた。

3 ) 父親として娘二人を片時も忘れずに想い続ける 喪失から 7 年の年月を経て，周囲や肉親でさえも亡
くなった我が子に関する話を出してこない。それは, あたかも我が子の存在が忘れられたかのような寂寞た る思いに駆られ，何より辛い思いへと陥らせる事であ つた。「周囲の記憶から薄机行く子どもの話をしたい」, 「自分には二人の子どもが居ると言いたい」と強く思 うようになっていった。

Data：「双子だから, 顔は想像できるじやないですか $\cdots$ な んかことあるごとに, やっぱり二人いる光景を想像する んですよね。ここにが居ればすごい楽しいだろうなっ て。今でもやっぱり卒園式とか, 入学式とか, 運動会と か, 行事とか節目とか, そういう時になると, やっぱり 二人一緒に居る光景を想像しちゃうんですよね」

4 ）我が子と出会い死生観が変わる

D氏は，自らを「現実主義者」で「神様とか信じな い」,「死後の世界とか全然信じない性格」であるとい う。しかし, Iちゃんと「出会い」, 自身に変化があっ た。Iちゃんを想い続ける気持ちが強く，そして現在 も「当然」父親であるからこそ「天国に行けば娘に会え る」と不思議と信じられる気がした。時に,「何もして あげられなかった」と嘆く事もありながら, いつか「家 族四人でそろえる日」を待ち侘びていた。

5. E氏の体験：30代。J君を亡くして2年が経過して おり, インタビュー当時, 妻は第二子を妊娠中であっ た。

〈E氏の体験の解釈〉 妻の入院に安心していた中の思 いがけない喪失であり, 別れの時間を親子三人で過ご したいと思ったが，妻に代わって周囲とのやり取りを 引き受けた。我が子を失った悲しみを社会から認めら れなかったが，妻と話し合うことで心の安らぎを得て いた。時を経た今, 子を想って悲しむのではなく, 常 にすぐ傍に存在を感じて愛しみ続けている。

1) 我が子の死に現実感を喪失する

病室に駆けつけると, 妻が我が子に泣いて謝る姿が 目に飛び込んできた。E氏は自身の感情と向き合う間 もなく, 降りかかってくる手続きを「訳が分からない まま，言われた通りにこなす」だけで精一杯であった。 Data : 「悲しいとかっていうのが無かったんです, その時 は。妻の方が落ち込んで泣いていたじやないですか。だ から，そっちのほうが心配な方が強くて。事務処理が一 通り経わって, 部屋で三人になれたらやっと, 赤ちゃん が死んじやったっていうことの実感が出て…初めてそこ で悲しい気持ちがら゙わっと出て, 涙が出てきた…」 
2 ) 周囲とのやりとりを妻に代わって引き受ける

E氏は，妻が悲しみに打ちひしがれる姿に最も心を 砕かれた。周りの雑音に立ち入られることなく「ずっ とJに触れていたい」という妻の思いに添う為，外界 とのやりとりを全て引き受けていた。 $\mathrm{E}$ 氏は「本当だ つたら楽しい買い物が出来たはず」の育児用品売り場 に初めて出向き，「Jを天に送りだすための洋服」を自 ら探し出さなければならなかった。

Data：「妻と」を病室に置いたまんま,一人で出て行った時 が一番辛かったかな。(中略) 出生届けと同時に死亡届け も出さなきやいけないっていうのが, なにしろ辛くて。 ルに服を買って戻ってきた時, 妻と」とお義父さんが居 たんですけど，買った服に着替えさせる時に，お義父さ んに席を外してもらって…た淚が出てきちゃって。僕 がしつかりしていないのを見ちゃうと心配になっちゃう だろうなあと思って」

3 ）亡き我が子の存在を認め奻会で生きる

我が子に関して周囲が「何も触れない」ことは自分 を労わる気遣いであろうと受け取っていたが，本心で はJ君のことを話題に出して欲しかった。亡き子の話 が日常に出てこない事に戸惑いを覚え,「腫れ物に触 る」かのような関わりは，父親としての立場を脅かさ れた。J君の存在を「無かったことにされちゃう」こと を最も恐机ていた E⿱氏丶，周囲に話したいという思い は積もる一方であった。しかし，心ない他者に我が子 の話をした際に『そっか, また頑張りなよ』と,「赤ち やんの死を一人の人間の死として認めてもらえない」 現実に直面し, 悲しみを増していた。

4 ）我が子と共に成長をする

E氏は，J君の法要があるたびに「少しずつ」思い出 の品を供養しては，自身も「少しずつ」成長している ように感じていた。以前は, 我が子に関するものは何 でも手元に残していたが，今では常にすぐ傍に存在を 感じられる我が子であるからこそ「僕の中では生きて いる元気な子と変わらない感覚で接している」と語り, 思い出の品も手放すことが出来るようになっていた。

6. F氏の体験：40代。K君を亡くして 2 年 7 ケが経 過していた。インタビュー当時, 生後 9 ケ月になる第 二子を授かっていた。

〈F氏の体験の解釈〉我が子の予期せ女死に衝撃を受 け, 自責感を抱く妻と共に周囲との交流を絶ち, 引き こもつた。死因を知ることで苦悩は僅かに和らいだが, 子どもの治療が出来ない出産施設を選択したこと, 次
子を理想的な環境で授かったことで空虚感と後悔は増 した。我が子から教えられた意味を伝えるべく，それ を社会に周知させるために動き出していた。

1) 自責の念を持つ妻と共に苦しむ

自責の念を持った妻を見守ることは長きに渡る「一 番大きな問題」であり, 妻の嘆き悲しむ姿を見ること は何より辛いことであった。ましてや，我が子を愛す るが故に『私のせいだ』と, 行き場の無い悲しみを妻 が自身に向ける姿は，F氏には非常に辛くいたたまれ ないものであった。

Data：「自分の悲しみよりも，妻の悲しみばかりを考えて いた。(中略) 一緒に居る人がすごく辛い状態にいると, こちらもすごく辛いわけですよ。で, 僕の方はそれほど 直接, 死んだことを悲しんでいないように, 彼女からは 見えちゃうんだろうと思うんだけど(僕も悲しい)。色々 対立したこともあるし，お互いにすごく辛い時期がずー つと続いて…でも, 解剖の結果とかが出て少しおさまっ たのかな」

2 ）次子を育てる中に空虚感を抱く

第二子を授かった現在，「実際に育児に関わってみ ないと, 母親程の喪失は実感出来ない」,「子どもとず つと一緒に過ごしてきた妻だからこそ辛い」と感じて いる。日々, K君の表情や性格, 成長していたであ ろう姿を想像しては「共に過ごした時間が無い」こと, 「子どもの治療が出来ない」施設を選択したことを悔 いた。F氏は次子を理想的な環境で授かった後に，K 君の存在を更に「忘れたくない」と願うようになった。 そのことから, 我が子から「教えられた」意味を執筆 活動や子どもを亡くした親の会などへの参加を通して, 社会全体に広めるべく行動に向かっていた。

Data：「生まれるまでに一生懸命やってきたのに何にも残 んなかったっていう, そういう虚しい気持ちはすごくあ ったんですよね。子どもが手をすり抜けていったみたい なね。悲しいとかいうよりも…(中略)今の子をみていて, 同じように成長していたらなあ, という気持ちはすごく ありますね」

\section{7. 死産・新生児死亡で子どもを亡くした父親達に共 通する体験の特徵}

6名の研究参加者に共通してみられた体験の特徵を 類型化した。その体験は, 以下の7つに分類された。1. 予期せ女死に衝撃を受ける。2. 自分の悲しみをこらえ 妻の心身を案じる。3. 辛さを隠し父親・夫としての役 割を果たす。4. 社会に傷つけられながら生活を続ける。 
5. 子どもの死因を知りたいと望む。6. 父親として在り 続ける。7. 人間的な成長を遂げる。

研究参加者 6 名の体験は子ぞもを授かった時期か ら喪失，そして現在に至るまでの固有のものであり， 個々の経験から培われてきた価值観および人生観に基 づき語られた。本研究においては, 研究参加者が語り たいことを語ってもらうことを主としているために， 内容はおのずと個別なものとなっているが，その中に は同時に共通性も見えている。

\section{IV. 考察}

死産・新生児死亡によって子どもを亡くした父親が 体験した7つの特徴の中から,「覆われている父親の悲 しみ」,「妻を守るという役割」,「喪失に対する意味付 けをするということ」に関して考察する。

\section{1．覆われている父親の悲しみ}

本研究における父親全員が，元来他者に相談はしな い性格であると述べ，5名が子どもの喪失体験に関わ る相談を他者に行わなかった。そして父親達の心中で は，子どもを亡くした衝撃や悲しみを抱きながらも 「全部自分がしないといけない (A氏)」「「自分がくよ くよしていたらどうしょうもない $(\mathrm{C} 氏 \mathrm{E}) 」, 「$ 自分がし

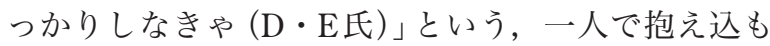
うと特性が認められた。死産の経験がある父親は，自 分の子どもを妊娠中に守れなかったことと，育てるこ とが出来なかったという後悔の念を持ち，子どもの喪 失を嘆く (Worth, 1997)。さらに，妊娠に関すること は女性だけの経験と考えられ，父親は無視されている ように感じ (O’Leary \& Thorwick, 2006)，その衝撃か ら立ち直る時間を与えられないままに，家族を守る役 割，夫として妻を守る役割，社会より求められる男性 としての強さを持つように振舞わざるを得ない $(\mathrm{Mc}$ Creight, 2004 ; Murphy, 1998 ; Worth, 1997) と指摘さ れている。また，Davis (1996) は，父親の悲しみは心 の奥深く溜め込まれ，潜在意識下にあるために“見え ない悲嘆” (Invisible grief) であると述べている。加え て，日本においても男性は感情を抑えることが望まし く，強くなければならないとされ，他者からもそのよ うに期待される(小松・岩田, 1989) ことから，強くあ ろうとする父親役割は欧米と我が国において共通する ものであることが示唆された。

一方，そのような男性特有の役割を備えているがゆ えに, 男性の抱く悲しみは複雑化することがあると
警鐘を鳴らす研究者が複数存在している $(\mathrm{McCreight,}$ 2004 ; Murphy, 1998；Worth, 1997)。周産期に子ど もを失う悲しみが “非公認の悲嘆” (disenfranchised grief）(Doka, 1989）と言い表されるように，父親らは 社会において嘆き悲しむことを認められず，支援も与 えられないという現状がある。また，妊娠や出産の主 体が女性であることにより, 父親の悲しみは社会から 気に掛けられることなく見過ごされてきた (Murphy, 1998)。本研究の父親達も, 周囲からの『また頑張り

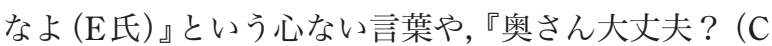
氏）』という妻の身を気遣う声かけに，自身の悲しみ は見過ごされていると感じさせられていた。そして， 子どもは “存在しなかった者”として周囲に扱われた 事により，さらに悲しみを増していた。

このように，父親達の抱く悲しみが覆われることの 背景として，父親自身の特性である自らの悲しみを抱 え込み表面化されていないこと，そして社会の無理解 から子どもの死を嘆き悲しむことを認められていない ことが存在している。

\section{2. 妻を守るという役割}

本研究の父親達は, 「妻が一番辛い立場である $(\mathrm{A}$ 氏）」，「妻が帝王切開をしなければならないと思った （B氏・C氏)」,「妻が一番ぼろぼろになっちゃった (C 氏）」と語ったように，我が子の死を知らされた衝撃 の直後に，自身の悲しみを表出するより先に妻の身体 に受ける痛みに目を向けていた。Samuelsson，Radestad, \& Segesen (2001) によると，死産を告げられた父 親は葛藤と無力感を抱きながらもパートナーを支えよ うと努め，その身体に痛みや合併症がもたらされる ことを恐机ていたという報告しており，本研究におい ても同様の結果がみられた。さらに本研究の父親達は, 先の Samuelsson, Radestad, \& Segesen (2001) が述べ た“身体的痛み”だけではなく“精神的痛み”にも目を 向けていたことは明らかであり，妻の悲しみを目にす ることで父親も同調するかのように苦悩を辿っていた。 このような父親の思いは，Theut, Pedersen, Zaslow, et al. (1989) が夫婦を対象にした悲嘆の研究によって報 告した，女性は妊娠期より子どもと共に生活するとい う身体的違いを持つ事から，周産期の喪失は女性の方 が衝撃を強く受けると考元られるという仮説を支持す るものと考えられた。しかし，その仮説により父親の 存在が見過ごされ，「妻の方が辛い」と語られたように， 自身の感情を他者に打ち明けることのない父親の悲し 
みは，自身の意識せぬうちに押し隠されてしまうこと が危ぶまれる。また，父親の悲嘆が時に母親より遅れ て現れるという報告があるように (Vance, Boyle, Najman, et al., 2002), 子どもの喪失から半年後にパニッ ク障害が発現した $\mathrm{A}$ 氏は, 多くの喪失を一人で抱え込 み続けていたことが引き金になっていたと考えられる。 このように無意識に悲しみを覆い隠して女性を守る等 の問題に直面する父親の役割は, 周囲からのサポート を受ける機会を逸し，その悲嘆過程が遅延される可能 性があることが示唆された。

\section{3. 喪失に対する意味付けをするということ}

本研究における5 名の父親達は, 大きな衝撃を受け ながらも子どもが亡くなった原因を知りたいと望み, 「死に納得出来ない $(\mathrm{A}$ 氏・ F氏 $) 」$, 「死の原因をうやむ やなままにしておきたくない $(\mathrm{C} 氏)$ 原死んだ原因を 明らかにしたい (B・D氏)」と語った。そのうち明白 な死因を知り得た父親は 3 名であった。一方, 死因が 分からなかった $\mathrm{A}$ 氏は「納得が出来ない」と, 現在も その原因を探しており, B氏は夫婦が抱えていたス卜 レスが原因で「誰が悪いわけでもない」と結論付けて いた。このことは, 子どもを亡くした父親達にとって, その死になんらかの意味を持たせることは共通して求 めた“問い”であったと考えられた。Neimeyer (1997) によると, 死別において中心的な課題は意味付けるこ と, もしくは意味を再構築することにあるという。つ まり，死因を明らかにし，新たに自身の認知領域にお いて死の意味付けを行うことは, 死別の悲しみを和ら げる力になり得るということを指している。 D・F氏 は死別後に子どもの死因を明らかにするために解剖を 行ったが, Rosenblatt (2000) は, 解剖をすることは遺 された者が亡き者の死を受け止め, 死に対してなんら かの意味付けするための最初のステップであり, 亡く なった子どもに対する社会で認められた権利であると 述べている。例えば，F氏が「妻の自責の念を取り除 く為にも, 子どもの死因を知りたい」と語ったように, 子どもの死の原因を知ることによって, “妻が脅かさ れている原因を取り払うことが出来る”という意味を 見出していた。また，D氏は，Iちゃんが深刻な先天 性疾患で根治が難しく, 妻と次女の身体には影響が及 ばないと “教えてくれたこと”と意味付けることによ って，悲しみの中にも安堵感を抱いていた。DeFrain， Martens, Stork, et al. (1990) は, 解剖をすることは “死 の儀式”のようなものであると述べているが, 本研究
からも, 解剖を選択して死因を知ることは, 遺された 者の苦悩を和らげ，悲しみを少しずつ癒す一助となり 得ることが考えられた。

\section{4. 死産・新生児死亡によって子どもを亡くした父親 への支援の可能性}

父親達は, 強く在ろうという備え持った意識のため に悲しみが表面化され難く, 悲嘆過程が遅延する可能 性があることを示唆されたことから，医療者は父親も 支援が必要な対象であることを再度認識すべきである。 父親達を取り巻く家族や重要他者に, 父親も母親と同 じ苦悩を辿る存在であることを伝え, 相互の理解を促 すことが重要であろう。また, 本研究の父親達の中に は, 子どもの死因を知ることは, 子どもが伝えたかっ たことをくみ取ることであり，それをすることが親の 役割と考えている者や, 死因を知る過程を通じて喪失 の意味を深く考える者もいた。このことから，悲し みのさなかにも, 医療スタッフと対話する機会をいつ でも提供出来ることや，解剖を行うことの意味を伝え， その意思決定の過程を支える関わりが必要である。さ らに, セルフヘルプグループへの参加は母親・父親と もに増加傾向にあり，ニーズが高まっている(太田・ 石井・堀内他, 2009) ことから, 父親にも自身の思い を語ることが出来る場を地域で提供するべく体制作り が求められている。

\section{5. 本研究における限界}

本研究は参加者が少数であることから, その人数を 増やし, 父親への更なる理解を深めることが必要とさ れる。また, 本研究は自身の体験を語ることが出来る 方をリクルートしているため, データに偏りがある。

\section{V. 結 論}

死産・新生児死亡によって子どもを亡くした父親は， 悲しみを押し隠しながらも父親と夫の役割を果たして いた。表面化されない悲しみは社会から見過ごされて いたが，子どもの存在を忘れることはなく，父親とし て在り続けていた。

\section{謝 辞}

本研究にあたり,お子様との思い出をお話ください ましたお父様方に心より感謝申し上げます。そして研 究全般にわたりご指導いただきました聖路加看護大学 
の堀内成子教授ならびに伊藤和弘教授に感謝申し上げ ます。本研究は2007年度聖路加看護大学大学院博士 前期課程に提出した修士論文の一部に加筆・修正した もので，第7回日本遺伝看護学会学術集会で結果の一 部を発表した。

\section{文 献}

Badenhorst, W., Riches, S., Turton, P., \& Hughes, P. (2006). The psychological effects of stillbirth and neonatal death on fathers: Systematic review. Journal of Psychosomatic Obstetrics and Gynecology, 27(4), 245-256.

Condon, J.T. (1986). Management of established pathological grief reaction after stillbirth. American Journal Psychiatry, 143(8), 987-992.

Davis, D.L. (1996). Empty cradle, broken heart: surviving the death of your baby. revised and expanded edition. Golden Co: Fulcrum Publishing.

DeFrain, J., Martens, L., Stork, J., \& Stork, W. (1990). The psychological effects of a stillbirth on surviving family members. Journal of Death and Dying, 22(2), 81-108.

Doka, K.J. (1989). Disenfranchised grigf. In K. J. Doka (Ed.). Disenfranchised grief: recognizing hidden sorrow (pp.111). Lexington, MA: Lexington Books, 1-11.

Dyregrov, A., \& Dyregrov, K. (1999). Long-term impact of sudden infant death: A 12-to 15-year follow-up. Death Studies, 23(7), 635-661.

藤村由希子，安藤広子 (2004)。岩手県における死産，早 期新生児死亡に対するケアの実態調査．岩手県立大学 看護学部紀要, $6,83-91$.

Giorgi, A. P. (2004)。吉田章宏訳・構成，特別記事経験 記述資料分析の実際現象学的心理学の「理論と実践」. 看護研究, 37(7), 607-619.

蛭田明子 (2009)。死産を体験した母親の悲嘆過程におけ る亡くなった子どもの存在. 日本助産学会誌，23(1), 59-71.

Hughes, C.B., \& Page-Lieberman, J. (1989). Fathers experiencing a perinatal loss. Death Studies, 13, 537-556.

石井慶子(2006)。医療者の心無い言葉・嬉しかった言葉一 活動から見えてきたもの。助産雑誌，60(11)，942-945.

Kavanaugh, K. (1997). Gender differences among parents who experience the death of an infant weighing less than 500 grams at birth. Omega, 35(3), 281-294.

小松美穂子，岩田知子 (1989)。新生児を亡くした両親の 悲しみの分析．筑波大学医療技術短期大学部研究報告,
$10,23-34$.

Murphy, F.A. (1998). The experience of early miscarriage from a male perspective. Journal of Clinical Nursing, $7(4), 325-332$.

McCreight, B.S. (2004). A grief ignored: Narratives of pregnancy loss from a male perspective. Sociology of Health and Illness, 26(3), 326-350.

Neimeyer, R.A. (1997). Meaning, reconstruction and the experience of chronic loss. Living with grief: when loss is prolonged (pp159-176). Washington, D.C.: Taylor \& Francis.

大井けい子 (2001a)。胎児または早期新生児と死別した母 親の悲哀過程：悲嘆反応の様相 (第一報)。母性衛生, 42(1), 11-21.

大井けい子 (2001b). 胎児または早期新生児と死別した母 親の悲哀過程 : 死別に関する母親の行動 (第二報)。母 性衛生, 42(2), 303-315.

太田尚子 (2006)。死産で子どもを亡くした母親たちの視 点から見たケア・ニーズ. 日本助産学会誌, 20(1), 1625.

太田尚子, 堀内成子, 石井慶子, 蛭田明子, 鷲尾美代子 (2009)。ペリネイタル・ロスを経験した両親へのグ リーフケア—「天使の保護者ルカの会」5年間の活動—. 第15回日本臨床死生学会大会抄録集, 79 .

岡永真由美 (2005)。流産・死産・新生児死亡にかかわる 助産師によるケアの現状. 日本助産学会誌, 19(2), 4958

O'Leary, J., \& Thorwick, C. (2006). Fathers' perspectives during pregnancy, postperinatal loss. Journal of Obstetric Gynecologic \& Neonatal Nursing, 35 (1), 78-86.

Rosenblatt, P.C. (2000). Parent grief: Narratives of loss and relationship. Philadelphia: Brunner/ Mazal.

Samuelsson, M., Radestad, I., \& Segesen, K. (2001). A waste of life: Fathers' experience of losing a child before birth. Birth, 28(2), 124-130.

Stinson, K., Lasker, J., Lohmann, J., \& Toedter, L. (1992). Parental grief following pregnancy loss: A comparison of mothers and fathers. Family Relaions, 41, 218-223.

Theut, S.K., Pedersen, F.A., Zaslow, M.J., Cain, R.L., Rabinovich, B.A., \& Morihisa, J.M. (1989). Perinatal loss and parental bereavement. American Journal of Psychiatry. 146(5). 635-639.

Vance, J.C., Boyle, F.M., Najman, J.M., \& Thearle, J.M. (2002). Couple distress after sudden infant or perinatal 
death: A 30-month follow up. Journal of Pediatrics Child Health, 38(4), 368-72.
Worth, N.J. (1997). Becoming a father to a stillborn child. Clinical Nursing Research, 6(1), 71-89. 